\title{
RECENZJE
}

Klio. Czasopismo poświęcone dziejom Polski i powszechnym

PL ISSN 1643-8191, t. 31 (4)/2014, s. 165-240

\section{Tomasz Falkouski, Myśl i zdarzenie. Pojęcie zdarzenia historycznego w historiografii francuskiej XX wieku, UNIVERSITAS, Kraków 2013, ss. 393}

(c) $(1) \Theta$

http://dx.doi.org/10.12775/KLIO.2014.062

Tym, co uderza w książce Myśl i zdarzenie Tomasza Falkowskiego, jest wydaje mi się czymś rzadkim i cennym, czymś, co sprawia, że pracę tę chce się określać jako dojrzałą, pełną, domkniętą myślową całość. Sam autor stwierdza, że jego „studium - przynajmniej w swych założeniach - ma ściśle określony, wielostronnie ograniczony i przez to dość dokładnie sprecyzowany charakter" (s. 39-40). Nie jest to deklaracja gołosłowna. Uzasadnia ją kontekst obszernego „Wstępu” metodologicznego, którego lektura wymaga być może największego skupienia ze wszystkich partii książki. Precyzja, nawet drobiazgowość, z jaką Falkowski wypreparowuje tam przedmiot i narzędzia swych badań, sprawiają, że podejrzliwe, szukające sprzeczności czytanie jego pracy wydaje mi się podejściem zupełnie niepotrzebnym i jałowym. Przy wszystkich swoich zaletach metodologiczny rygor wiąże się jednak z ostrożnością, ta zaś często przejawia się głównie wątpliwościami i skłonnością do poprzestawania na formułowaniu problemów, do unikania jednoznacznych rozstrzygnięć intelektualnych, a zwłaszcza tego, co można by nazwać wyborami ontologicznymi. Nie jest to przypadek Falkowskiego. Nie tylko zajmuje się on explicite właśnie „zdarzeniową ontologizacją przeszłego zjawiska” (s. 17), ale też wyraźnie opowiada się po stronie konkretnej tradycji filozoficznej, na gruncie której takie badania brzemienne są postulatami natury metafizycznej. W jakich miejscach i formach tego rodzaju 
zdecydowanie przejawia się w pracy, która ,jest założona jako studium wyłącznie analityczne" (s. 40)? Moja lektura książki Falkowskiego skupiła się stopniowo na tym pytaniu jako przewodnim.

Zanim jednak będzie można podążyć tym tropem, należy przedstawić sam przedmiot analiz przeprowadzonych w Myśli i zdarzeniu, ich porządek i zakres. Pozwoli to, jak mam nadzieję, zasugerować czytelnikowi wielość możliwych lektur tej książki oraz perspektyw, które otwiera. Materiałem badań - czy raczej, jak inspirując się Gilles'em Deleuze'em wolałby to określać autor, „eksperymentów” - jest historiografia francuska XX wieku. Celem - wypreparowanie z tego materiału „pojęcia zdarzenia”. Tę laboratoryjną metaforykę sugeruje sam Falkowski, pisząc o „sztucznej, właśnie eksperymentalnej przestrzeni”, w której umieszcza historiograficzne wypowiedzi o historycznych wydarzeniach, a następnie podchodzi do nich uzbrojony w „cały szereg analitycznych instrumentów i "odczynników»" (s. 39). Na arsenał ten składa się zestaw kryteriów pozwalających rozpoznać pojęcie (zdarzenia historycznego) pośród innych jednostek dyskursywnych oraz pewna liczba założeń dotyczących tego, czym jest „dyskurs” jako taki. Licząc na admirację, którą autor żywi dla Foucaulta, pozwolę sobie więc ograniczyć się do hasłowego określenia zastosowanej w omawianej książce metody „archeologią wiedzy”. Jest to tym bardziej uzasadnione, że metoda ta jest stosowana z kunsztem i pracowicie, co sprawia, że nawet jeśli zatrzymamy się na tym poziomie lektury Myśli i zdarzenia - Falkowski podkreśla taką możliwość parokrotnie - nie będziemy rozczarowani.

Imponuje przede wszystkim „archiwum” analizowanych wypowiedzi. Bezpośredniej analizie poddanych zostaje ponad dwadzieścia francuskich prac historiograficznych, w wielu wypadkach nieprzełożonych na język polski, a napisanych między drugą połową lat sześćdziesiątych ubiegłego a pierwszą dekadą naszego wieku. Daty tych publikacji świadczą o tym, że chodzi o problematykę wciąż aktualną, a więc zawierającą dla wszelkiego typu refleksji historycznej pewien ładunek praktyczny. Pożytki takie Falkowski obiecuje we wstępie, wskazując na dwie korzyści płynące z jego ustaleń dla „historycznej praktyki badawczej”: po pierwsze, chodzi o uzyskanie większej kontroli nad konceptualizacją badanych „zjawisk-wydarzeń”, po drugie, o poszerzenie „kkwestionariusza badawczego» mającego zastosowanie do tego typu historycznych fenomenów” (s. 43). 
Następnie autor w czterech rozdziałach stanowiących rdzeń jego pracy rekonstruuje cztery różne, zaistniałe na gruncie XX-wiecznej historiografii formy pojęciowe zdarzenia historycznego: „zdarzenie strukturalne”, „mikro-zdarzenie”, „zdarzenie dyskursywne” i „obiekt zdarzeniowy”. Każda z tych „systematyczności teoretycznych” oznacza inny zestaw pytań, jakie postawić można zjawisku rozważanemu jako wydarzenie. Właśnie zwięzłe streszczenie tych czterech „kwestionariuszy badawczych” Falkowski prezentuje w "Zakończeniu” jako owoc swoich analiz, potwierdzający, że „nasze przedsięwzięcie się powiodło” (s. 361). Pytając o „wydarzenie strukturalne” G. Canguilhem, M. Foucault, P. Bois, N. Wachtel i P. Toubert uczą poszukiwać akcydentalnego zjawiska, które przez nagłe zajęcie systemowej, centralnej pozycji w strukturze historycznej kładzie jej kres i powoduje międzystrukturalną transformację. Gdy historyk zawiesza wszelką historiozoficzną „doniosłość” wydarzenia i bierze je pod mikroskop, to - jak pokazuje Falkowski, analizując aż siedem różnych prac - czyni tak, by przekształcić „obiektywne fakty” w enigmatyczne znaki, które odsyłają do historycznych realności wykraczających poza obręb badanego zajścia, czyniąc zeń „historyczny rewelator” (s. 142). Poszukiwanie wydarzeń historycznych w szeroko pojętej sferze mowy wymaga z kolei potraktowania jednostek dyskursywnych (słów, wypowiedzi, opowieści itd.) jako zjawisk rzadkich i wyjątkowych, nieredukowalnych do ich szerszego kontekstu, a badanych raczej w odwołaniu do swej pragmatycznej sprawczości, „bezcielesnej materialności” (s. 260) i polityczności, które wynikają z genealogicznego zakorzenienia dyskursu w konkretnych relacjach władzy. Rekonstruując za P. Veyne'em i Foucaultem możliwość badania historii przez pryzmat pojęcia „obiektu wydarzeniowego”, Falkowski wskazuje natomiast na szereg pytań i procedur, które pozwalają zedrzeć z „rzeczy” pozór naturalności, odwieczności, oczywistości i obiektywności, by ukazać ją jako syngularny, tymczasowy korelat określonych praktyk historycznych, jako „bibelot” aktualizujący się w kształtach każdorazowo wyznaczanych przez „polimorficzny i heterogeniczny wielokąt drobnych przyczyn” (s. 358).

Ten zaprezentowany czytelnikowi jako puenta pracy „kwestionariusz badawczy” jest spisem pytań konkretnych oraz - o czym świadczy choćby sama wartość analizowanych przez autora prac historiograficznych - skutecznych. Eksplikowane metody indagacji materiału historycznego, choć 
często dość techniczne i angażujące skomplikowaną aparaturę pojęciową, dzięki temu, że ukazane zostają niejako w działaniu i na przykładach, wydają się niewydumane, a także zwyczajnie zrozumiałe i ciekawe. Tak, nie ulega wątpliwości, że zadeklarowane na wstępie rezultaty epistemologiczne analiza Falkowskiego rzetelnie osiąga. Tym bardziej warto zapytać, czy stawka jego rozważań nie jest jeszcze większa. Zastanawia na przykład, że choć owe „praktyczne korzyści” badawcze stanowią „Zakończenie” książki (s. 361-366), to jako jej cel zapowiedziane są w miejscu nietypowym, bo w ostatnim przypisie „Wstępu” (s. 43). Zwróćmy się więc teraz nie ku rezultatom, ale ku intencjom lub źródłom omawianej pracy. Tu właśnie Falkowski dokonuje wyborów filozoficznych, których stosunek do jego własnych analiz dyskursu historiograficznego wydaje mi się dający do myślenia.

Jak już podkreśliłem, wybory te dokonywane są w sposób zdecydowany, a więc jawny i raczej jednoznaczny, choć - jako że nie stanowią bezpośredniego przedmiotu rozważań - nie do końca wyeksplikowany. Od razu w pierwszym więc zdaniu Falkowski wskazuje jako źródło swych dociekań „pytanie sformułowane swego czasu przez Michela Foucaulta: czy w XX wieku istnieje coś ważniejszego do pomyślenia niż zdarzenie?” (s. 5). Otóż czytając tę deklarację, warto pamiętać o specyficznym kontekście, w którym autor Historii szaleństwa poczynił tę sugestię. Pada ona w artykule Theatrum Philosophicum z 1970 roku, który poświęcony został dwóm książkom Deleuze'a: Różnicy i powtórzeniu (1968) oraz Logice sensu (1969). Jest to tekst pełen wątków ubocznych i wysoce niejednoznaczny, który wyraża głęboką pochwałę i wspólnictwo z dziełem Deleuze'a, ale czyni to, sięgając niekiedy po takie środki jak przesada czy przyjacielska parodia. Sam Deleuze twierdził, że ujawniło się w tym artykule coś z „diabolicznego poczucia humoru" "Foucaulta. Główna teza tekstu, przynajmniej w warstwie „recenzyjnej”, głosi, że dzięki Różnicy i powtórzeniu oraz Logice sensu „możliwa jest myśl o tym, co nowe”2, a więc właśnie o „zdarzeniu”: „Myśleć zdarzenie czyste, to przede wszystkim dać mu jego metafizykę" i to właśnie czynić ma Deleuze, zrywając z „metafizyką substancji, mogącej stanowić

${ }^{1}$ G. Deleuze, Negocjacje. 1972-1990, tłum. M. Herer, Wrocław 2007, s. 98.

${ }^{2}$ M. Foucault, Theatrum Philosophicum, [w:] idem, Filozofia - historia - polityka. Wybór pism, tłum. D. Leszczyński i L. Rasiński, Warszawa-Wrocław 2000, s. 77. 
wsparcie dla przypadłości” i „metafizyką koherencji, która lokowałaby je [zdarzenie] w splątanym nexus przyczyn i skutków”" Falkowski oczywiście doskonale zna ten kontekst, ale co ciekawsze, wydaje się również weń w jakiś sposób wpisywać. Posługując się dystynkcjami filozoficznymi zaczerpniętymi ze słowników Foucaulta i Deleuze'a, stwierdza bowiem dobitnie: „W realnym i chyba wciąż (znów?) aktualnym sporze między "specyfiką" a «jednolitością», "różnicą» a "tożsamością», "osobliwym» a "fundamentalnym», «szczególnym» a "ogólnym», opowiadamy się po stronie pierwszego obozu" (s. 43).

Falkowski nie uprawia jednak przecież „metafizyki zdarzenia czystego”. Pomyśleć chce „zdarzenie historyczne” (s. 5), a dokładniej różne pojęcia zdarzenia specyficzne dla współczesnego dyskursu historiograficznego i stanowiące jego „formy racjonalności” (s. 34). Jaki zachodzi związek między foucaultowsko-deleuzjańską „ontologią różnicy, specyfiki, osobliwości i szczególności” a analizą „zdarzeniowej ontologizacji przeszłego zjawiska” w ramach współczesnej historiografii francuskiej? Jest to, jak sądzę, miejsce, w którym książka Falkowskiego otwiera się na różne możliwe interpretacje. Nie ryzykując, ale także nie tłumacząc wiele, można przyjąć, że to nawiązanie do pewnej filozoficznej tradycji odgrywa rolę „inspiracji”: dostarcza pojęciowych narzędzi, poszerza archiwum analizowanych wypowiedzi, być może wytycza szerszą perspektywę intelektualną, w ramach której autor realizować chce swoje własne cele. Kiedy jednak już raz zacznie się czytać Myśl $i$ zdarzenie pod kątem pojawiających się w niej odniesień do prac stricte filozoficznych (czyli w decydującej mierze tekstów Foucaulta i Deleuze’a), nie sposób nie zacząć doszukiwać się w tej książce interesujących komentarzy do tego mglistego przecież projektu, którym jest „metafizyka zdarzenia” bądź „różnicy”.

Przede wszystkim warto zwrócić uwagę na to, że Falkowski dokonuje jeszcze jednego wyboru filozoficznego, opowiadając się za radykalnym rozumieniem wniosków płynących z archeologii wiedzy. Deklaracja ta wyrażona zostaje w następującej formie:

3 Ibidem, s. 57. 
Usiłując zatem z(re-)konstruować formy pojęciowe zdarzenia historycznego w ich dyskursywnym, a nie świadomościowym zaistnieniu, to znaczy próbując je wy-eksplikować z apriorycznej warstwy historiograficznego dyskursu, z poziomu nazywanego przez Foucaulta "pozytywną nieświadomością wiedzy», staramy się realizować jeden z wyznaczników tej tradycji myślowej, która z całą mocą i rzeczywiście przedkłada to, co konstruowane, nad to, co bezpośrednie, daną w formie wyniku nad daną w formie zjawiska (Bachelard), «racjonalne» nad "postrzegalnym» (Lévi-Strauss), «założone» nad «już powiedzianym» (Deleuze) (s. 36-37).

Filozoficznie nastawiony czytelnik chętnie odczyta te słowa jako akces do szeroko rozumianej tradycji transcendentalnej, która, najoględniej mówiąc, analizuje aprioryczne założenia poznania, by odsłonić ontologię, w której umieszczamy się, praktykując dany dyskurs. Tą drogą i niejako już na własną rękę wolno być może czytać Myśl $i$ zdarzenie jako cichą, ale odważną pracę nad ontologią zdarzenia historycznego jako elementem „metafizyki zdarzenia czystego”. Ograniczę się do wskazania dwóch wątków, które są szczególnie interesujące w trakcie takiej lektury.

Po pierwsze, chodzi o swoistą zależność postulowanej „filozofii zdarzenia” od refleksji historycznej. Foucault chwali Deleuze'a za to, że pokazał, jak można pomyśleć „pływające zdarzenie, nie obciążając go ziarnem rzeczywistej historii” ", co sam autor Różnicy i powtórzenia rozumie jako aluzję do swej „naiwności, nieociosania”, które sprawiły, że „nie przeszedł przez etap struktury ani przez lingwistykę, psychoanalizę, naukę czy nawet przez historię"5. Wiele w tym krygowania się, ale Foucault faktycznie nie bez powodów w całej swej twórczości decydował się jednak na różne sposoby „przechodzić przez historię" i to on w podwójnej roli historyka-filozofa jest jednym z głównych bohaterów książki Falkowskiego. Ze względu na swe cele myśl, która w centrum umieścić chce pojęcie „zdarzenia”, w naturalny sposób zakorzenia się na skrzyżowaniu refleksji krytycznej i historycznej. Chodzi o to, by kwestionując domniemaną naturalność, konieczność i źródłowość badanych fenomenów, podważyć oczywistość tego, czym sami je-

${ }^{4}$ M. Foucault, op. cit., s. 64.

${ }^{5}$ G. Deleuze, op. cit., s. 98. 
steśmy, co mówimy, myślimy i robimy. Filozofia realizująca swój krytyczny wymiar jako to, co Foucault nazywał „historyczną ontologią nas samych”, zainteresowana jest ustanowieniem i analizą pola zdarzeń, wobec którego nie istnieje żadna transcendencja. Zdarzeniem ma się okazać współczesna podmiotowość, wszelkie esencje i tożsamości, a przede wszystkim to, co aktualne, i to, co nowe. Czy tego rodzaju filozofia różniłaby się od refleksji historycznej tylko swą koncentracją na teraźniejszości? Czy wówczas sformułowany w „Zakończeniu” Myśli $i$ zdarzenia kwestionariusz badawczy dałby się wykorzystać również do filozoficznej diagnozy aktualności? Myślę, że z pracy Falkowskiego w istocie czerpać można również i takie inspiracje. Dzieje się tak jednak przede wszystkim dlatego, że autor wykazał, iż pojęcie zdarzenia historycznego nie jest ani jedno, ani proste, ani naturalne. Udało mu się tym samym zrealizować część swych zamierzeń i dotrzeć do tej teoretycznej warstwy dyskursu historycznego, która „myślowo odróżnia ów dyskurs od innych [...], a przede wszystkim od «świadomości potocznej» i rządzących nią/w niej "mniemań»" (s. 42). To z kolei pozwala zdać sobie sprawę z tego, że nawet jeśli ów trudny projekt, który określam tu „filozofią zdarzenia”, rzeczywiście interpretować można jako specyficzną postać refleksji historycznej, to na konstatacji tej w żadnym wypadku nie można się zatrzymać. Historiografia stała się obecnie formą refleksji tak istotną i intelektualnie wyrafinowaną, że nie wystarczy wskazać na nią jako na metodę krytyczną, a na „porządek historii” jako na jakąś ostateczną instancję ontologiczną, by uchwycić specyfikę myśli Foucaulta. Wydaje mi się zaś, że przynajmniej filozofowie wciąż zbyt często zadowalają się tego typu konstatacjami. Dlatego książka Falkowskiego, w której Foucault ukazany zostaje jako operujący trzema z rekonstruowanych pojęć zdarzenia historycznego („zdarzeniem strukturalnym”, „zdarzeniem dyskursywnym” i „obiektem zdarzeniowym") stanowi również nowatorski wkład w recepcję dzieła tego, dobrze już przecież w Polsce znanego, myśliciela.

Po drugie, chciałbym zasugerować, że jeśli - wbrew wyrażonym explicite celom autora, ale zgodnie z jego inspiracjami - czytać będziemy omawianą pracę w świetle pytań o ontologię zdarzenia historycznego, to jej puentą

${ }^{6}$ M. Foucault, History of the Project, [w:] The Foucault Reader, red. P. Rabinow, New York 1984, s. 351. 
i podsumowaniem może się wydać nie „Zakończenie”, ale ostatni rozdział. Poświęcony jest on bowiem właśnie „przejściu od «rzeczy» do "wydarzenia»" (s. 309), „od «obiektywności» naturalnej (koniecznej, niezbywalnej, niekwestionowalnej) do "obiektywności» zdarzeniowej (przygodnej, arbitralnej, przypadkowo wykształconej, podważalnej)" (s. 285), tak jak operacja ta przedstawia się w ramach teorii historii Paula Veyne'a, przyjaciela, sojusznika i wybitnego interpretatora Foucaulta. Czyż „obiektami zdarzeniowymi” nie są zarówno struktury długiego trwania z pierwszej części pracy, jak i historyczne realności, do których odsyłają fakty-znaki przynależne mikrozdarzeniu z części drugiej, a w trzeciej - formacje dyskursywne bądź „układy wypowiedzeniowe”? Wolno i warto przebiegać wszystkie rozdziały książki Falkowskiego w poszukiwaniu elementów wspólnych czterem prezentowanym przez niego pojęciom zdarzenia. Łączy je, jak sądzę, to, że zaprojektowane są na wzór tej „maszynerii, pozwalającej wprowadzić do samych korzeni myślenia: przypadek, nieciągłość i materialność”, którą Foucault zaszczepić zamierzał historii idei, czyniąc „wydarzenie” (dyskursywne) jej centralnym pojęciem. Jeśli posuniemy się jeszcze dalej i zapytamy, jakiej natury jest owa materialność świata historycznego, to natrafimy na pojawiające się we wszystkich partiach książki Falkowskiego pojęcie „wydarzenia-efektu”, które Foucault we właśnie przywołanym tekście postulował w następujących słowach:

Jeśli dyskursy powinny być przede wszystkim traktowane jako zbiory wydarzeń dyskursywnych, to jaki status należy nadać samemu pojęciu wydarzenia, które tak rzadko brali pod uwagę filozofowie? Oczywiście, nie jest ono ani substancją, ani wypadkiem, ani jakością, ani procesem; wydarzenie nie należy do porządku ciał. Zarazem jednak nie jest wcale czymś niematerialnym; to na poziomie materialności zawsze odnosi ono skutek, jest skutkiem; ma swoje miejsce i zawiązuje relacje. [...] Powiedzmy, że filozofia wydarzenia powinna posuwać się naprzód, w kierunku na pierwszy rzut oka paradoksalnym - bezcielesnego materializmu ${ }^{8}$.

${ }^{7}$ M. Foucault, Porządek dyskursu, tłum. M. Kozłowski, Gdańsk 2002, s. 42.

${ }^{8}$ Ibidem, s. 41. Por.: T. Falkowski, Myśl i zdarzenie, Kraków 2013, s. 260, gdzie przytoczony cytat omówiony zostaje obszerniej w kontekście „meta-fizyki wydarzenia dyskursywnego". 
Również z eseju poświęconego Deleuze'owi dowiadujemy się, że pomyślenie zdarzenia wymaga stworzenia adekwatnej metafizyki właśnie dlatego, że „fizyka zajmuje się przyczynami; jednakże zdarzenia, które są ich skutkami, już do nich nie należą". Wszystkie opisywane przez Falkowskiego typy zdarzenia są właśnie „swego rodzaju historycznymi efektami albo «konstytucjami»", a ich pojmowanie wiąże się nie z prostym ustalaniem przyczyn, ale „z poszukiwaniem historycznych instancji i warunków, które je wytworzyły bądź umożliwiły ich wystąpienie" (s. 233).

Ontologia, w ramach której kauzalność może zostać w ten sposób zastąpiona aktualizacją, okazuje się jednak nie być ontologią Deleuze'a, ale Veyne'a. Jest to świat, w którym badacz za wszystkim, co wydaje się niezmienną albo ewoluująca powoli tożsamością (taką jak „państwo”, „religia” czy „demokracja”), odkrywa specyficzne, syngularne obiektywizacje różnych zbiorów heterogenicznych praktyk („władza imperialna”, „pogaństwo”, „demokracja antyczna”). Owe obiekty zdarzeniowe, między innymi ze względu na cechującą je w oczach im współczesnych implicytność i „naturalność", nie powodują ani nie determinują wydarzeń jednostkowych, a jedynie je warunkują bądź umożliwiają. Stanowią one „wklęsłe formy, zarysowane wirtualności, wypełniane i urzeczywistniane przez podmiotową aktywność czy, ściślej rzecz biorąc, afektywną moc aktualizacji” (s. 342). W tym miejscu Falkowski wypowiada następującą uwagę o samych fundamentach bytu poddanego „procedurze «uzdarzeniowienia»" (s. 284):

Zgodnie z logiką tego modelu podstawową siłą historyczną nie są jakieś nadrzędne instancje, układy społeczne lub przeszłe zjawiska, mające jakoby odgrywać rolę przyczyn bądź czynników sprawczych tego, co się aktualnie dzieje i co dopiero powstaje. W pierwszym momencie trzeba raczej przyjąć istnienie niezdeterminowanej «siły wewnętrznej», twórczej i nieurzeczowionej «woli mocy» (Nietzsche), «pożądania»(Deleuze), które wynajduje i wykorzystuje potencjały zewnętrznej rzeczywistości, zewnętrznego środowiska. Jak pisze Veyne: „[C]złowiek posiada «wolę mocy», wolę aktualizacji, która jest nieokreślona [...]. Człowiek jest zwierzęciem aktualizującym i urzeczywistnia wszelkiego rodzaju wirtualności, jakie wpadają mu w ręce [...]” (s. 341).

9 M. Foucault, Theatrum Philosophicum, s. 58. 
Na gruncie historiografii to powołanie się na aktualizującą wirtualności „wolę mocy” czy „pożądanie”, do którego zmusza konsekwentna próba pomyślenia bytu jako zdarzenia, okazuje się zaskakująco zdroworozsądkowe. W historii mamy po prostu do czynienia tylko i wyłącznie z rozmaicie warunkowaną, ale nigdy nie całkowicie zdeterminowaną działalnością ludzką. Ze względu na rodzaj „naiwnego realizmu” wobec zjawisk należących do potocznego Lebensweltu, który - jak słusznie podkreśla na wstępie Falkowski - „wypływa z samej logiki poznania historycznego, z tego, czym de facto jest historia w swym sposobie funkcjonowania” (s. 18), dopóki pozostajemy w ramach refleksji historiograficznej, dopóty tego typu „bezcielesny materializm” zdarzenia-efektu wydaje się stosunkowo dobrze zabezpieczony przed osunięciem się w jakiś nowy rodzaj witalizmu czy ekspresywizmu substancji à la Spinoza. Nie jest zresztą wykluczone, że już od czasów Marksa historia służy współczesnej filozofii zainteresowanej zdarzeniem właśnie jako taki bezpiecznik chroniący jej materializm przed popadnięciem w kolejną formę metafizyki Tego Samego ${ }^{10}$. Czy filozofia potrafi zastąpić zdroworozsądkową nieproblematyczność Lebensweltu, która wytycza pole historiografii, jakimś opracowanym na własnym gruncie sformułowaniem tezy o „jednoznaczności bytu”, co - jak dowodził Foucault - konieczne jest, by pomyśleć zdarzenie czyste? Czy Deleuze’a koncepcja „bytu jako tego, co powtarzalnie orzeka się o różnicy" ${ }^{11}$ rzeczywiście, jak twierdził dalej, realizuje ten postulat? A jeśli tak, to czy uprawiana w ten sposób metafizyka zdarzenia niesie z kolei jakieś konsekwencje dla ontologii zdarzenia historycznego, a w dalszej perspektywie dla historiografii?

Powyższe pytania wykraczają poza studium Falkowskiego, są jednak przez nie inspirowane. Myśl i zdarzenie jest książka tak dobrze... przemyślaną, że starając się wydobyć jej znaczenia filozoficzne, nie zdołałem uczynić niczego więcej, niż prześledzić część filozoficznych lektur, które przywołuje

${ }^{10}$ Jak powiada É. Balibar, „stąd wynika otwarta z kolei przez Foucaulta aporia filozoficzna: moim zdaniem, polega ona nie tyle na trudności rozważania transformacji poprzez pewną "mikrofizykę władzy» (a więc w kategoriach aleatorycznych), ile rozważania historyczności poprzez materialność ciał, lecz bez wpisania wydarzenia historycznego i właściwych mu kategorii w horyzont metamorfoz życia - inna formę teologii" (É. Balibar, Trwoga mas, tłum. A. Staroń, Warszawa 2007, s. 259).

${ }_{11}$ M. Foucault, Theatrum Philosophicum, s. 69. 
jej autor. Ograniczam się więc tutaj do recenzji, a właściwie do afirmacji poprzez wskazanie niektórych tematów poważniejszej debaty, na którą zasługuje moim zdaniem dzieło Falkowskiego.

Jan Swianiewicz (Warszawa) 